\title{
LO MODERNO DE NUEVO. ARQUITECTURA EN ASTURIAS 1950-1965 Fernando Nanclares y Nieves Ruiz
}

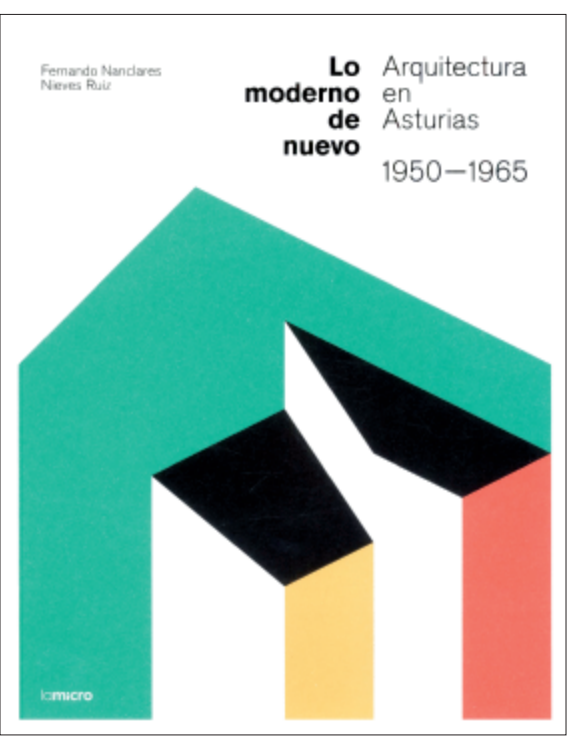

Prólogo de Antón González-Capitel Martínez

Madrid: La micro, 2014

376 págs.; ilustraciones en color; $21,5 \mathrm{~cm}$.

ISBN: 978-84-941342-1-0

Boletín Académico. Revista de investigación y arquitectura contemporánea

Escuela Técnica Superior de Arquitectura. Universidade da Coruña

elSSN 2173-6723

unw. boletinacademico.com

Número 5 (2015)

Páginas 73-74

Fecha de recepción: 27.10.2014

Fecha de aceptación: 04.11.2014

https://doi.org/10.17979/bac.2015.5.0.1040

La recuperación de la modernidad que tiene lugar en España después de la Guerra Civil y el inmediato periodo autárquico, encuentra en las periferias, alejadas de los principales centros de debate y divulgación que constituían Madrid y Barcelona, un fértil lugar dónde desarrollarse de una manera libre y personal, de la mano de arquitectos cuyo oficio condujo a realizaciones de gran interés que ahora comienzan a ponerse en valor.

La aparición de este libro viene a llenar un vacío, sólo estudiado parcialmente a través de aproximaciones previas desde la historia general de la arquitectura asturiana, o personificadas en la obra de determinados autores. Nanclares y Ruiz nos ofrecen un trabajo centrado exclusivamente en la recuperación moderna, que permite entender la complejidad, especificidad y calidad que ésta alcanza en la región entre 1950 y 1965.

La variedad de arquitectos y obras es abordada con concisión, organizando el discurso a través de un conjunto de temas que articulan la heterogeneidad presente en la ingente producción arquitectónica: la llegada del nuevo estilo, la integración de las artes, la posibilidad de un "grupo" de Asturias, la intervención de la Obra Sindical del Hogar, la arquitectura religiosa, la relación con la ingeniería —especialmente con aquella vinculada a los aprovechamientos hidroeléctricos- y la arquitectura proyectada desde Madrid.

Para acercarnos estas obras se recurre a una exhaustiva información gráfica, conformada por los documentos de proyecto, las fotografías de época, excelentes instantáneas actuales y reconstrucciones mediante infografías. El amplio trabajo documental — recurriendo a numerosas fuentes y archivos - queda patente en el resultado, certificando una auténtica «Edad de Oro» de la moderna arquitectura asturiana —acertadamente denominada así por Antón Capitel en el prólogo-, a la que este libro consigue otorgar un valor propio y diferencial. 
Ruiz y Nanclares, junto a la joven editorial independiente La micro, han conseguido llevar al terreno de la edición el rigor de la profesión y el cuidado por el detalle que hemos podido disfrutar en sus premiadas obras de escalas superiores. Pero también — y sobre todo— su amor por la arquitectura, en este caso por la arquitectura más próxima —a veces la más desconocida—, y que, gracias a esta publicación, podrá ser redescubierta y analizada con una nueva mirada: la que, con lucidez y minuciosidad, nos trasladan sus autores.

Lo moderno de nuevo es un libro que, por su dimensión y organización, puede servir también de guía para múltiples viajes por Asturias, permitiendo atractivas rutas a través de la arquitectura. Tengo que confesar que mi último viaje a Gijón y Oviedo lo hice levantando la vista más de lo habitual para intentar encontrarme con los edificios citados. Así, arquitectura y libro, libro y ciudad, entran en una sugestiva relación, abriendo numerosas posibilidades de lectura y disfrute.

Conviene, finalmente, recordar la llamada que hace Antón Capitel para construir en otros lugares investigaciones semejantes a ésta —cómo ya se está haciendo-, para cambiar la imagen que teníamos de la historia de la arquitectura espańola del siglo veinte por una más rica, matizada y compleja, logrando que lo moderno se conozca, se estudie y se valore, cómo avanza el título del libro, de nuevo.

\section{Antonio S. Río Vázquez}

